\title{
Experimental Study of Load Settlement Behaviour of Ring Footings for Different Internal Diameter Keeping the Contact Surface Area Same
}

\author{
Hitesh Rupani' ${ }^{1}$, Manas Bhoi ${ }^{1}$ \\ ${ }^{1}$ Pandit Deendayal Petroleum University \\ Raisan, Gandhinagar, India \\ hitesh.rcv15@sot.pdpu.ac.in; manas.bhoi@sot.pdpu.ac.in
}

\begin{abstract}
In some practical cases during the design of a foundation, ring configuration can be more preferred in comparison to the solid circular footing due to some field or topographical constraints. To address such issues and to reach a viable solution an experimental program was undertaken. This paper depicts the experiments conducted to study the load-settlement behaviour of ring footings on granular soil; under axial loading condition through Plate Load Test. The chosen ring footing was the special cases of the solid circular footing (Diameter $150 \mathrm{~mm}$ ); both having same contact area. The ring diameters chosen to achieve the same surface area are (in terms of $\left.\mathrm{D}_{\text {inner }}-\mathrm{D}_{\text {outer }}\right) 60-160 \mathrm{~mm}, 100-180 \mathrm{~mm}, 200-250 \mathrm{~mm}$. The ring Diameter ratio for each are $\mathrm{n}=0.375,0.555$, and $0.8 \mathrm{respectively}$. The Objective was to analyze the effect of increasing ring diameter ratio on the load-settlement behaviour while keeping the contact surface area same. The results show that bearing capacity of footing starts decreasing reasonably up to $n=0.375$ and afterward there is a steep decrease for $n=0.555$ and $n=0.8$.
\end{abstract}

Keywords: Bearing pressure, Settlement, Ring footing, Same contact surface area, Load v/s settlement.

\section{Introduction}

A Foundation must distribute loads of superstructure on a larger area such that soil below it does not fail in shear and settlement. As foundations have to resist vertical load, horizontal load and moments so it must be designed to prevent excessive settlement or rotation. Foundation design is one of the critical element in the geo-technical Infrastructure design. Circular foundations are provided where axi-symmetry is required in the plan. Many times, it happens that due to the topography and terrain conditions solid circular footings can't be provided; Ring footings are the alternatives to it. The ring foundations are mostly used in structures which are symmetrical such as transmission towers, thermal station towers, radar stations, TV antennae, chimneys, bridge piers, silos and liquid storage tanks, also the ring footings are more economical as compared with the other shapes of the footings, such as (strip, rectangular, square and circular footings). Ring foundations are often used for tall structures to resist lateral loads and to increase the stability against overturning. In addition, the ring footing provides better stability to the structures when compared to a solid circular footing with the same area.

Fisher [1] first studied the behaviour of hollow circular footings and the footing pressure. Later Ohri [2], Egorov KE. [3] and more recently Razavi and Hataf[4] have also studied the behaviour of hollow circular footings and its parameters. Gholami and Hosseininia [5] and Keshavarz and Kumar [6] derived the three bearing pressure factors $\left(\mathrm{N}_{\mathrm{c}}, \mathrm{N}_{\mathrm{q}}, \mathrm{N}_{\mathrm{y}}\right)$ for ring footings. Masoud Makarchian and Ehsan Badakhshan [7], in their paper stated that for the unreinforced condition, the square and circular footings having the same area almost have equal ultimate bearing capacity. Joon Kyu Lee and Sangseom Jeong[8] considered ring footings placed on a levelled system with layers finite thickness over a rigid base, the ring footing specified with inner and outer radii $\mathrm{Ri}$ and $\mathrm{Ro}$, respectively. In his [8] study, five inner to outer radius ratios ( $\mathrm{Ri} / \mathrm{Ro}=$ $0,0.2,0.4,0.6$ and 0.8 ) were investigated, this study implies that the wider ring footing has more settlement as compared to narrower ring footings given working load.

Going through various literature, it is found that many studies have been done for the hollow footings considering the ring diameter ratio, but still there is much scope of work for the ring footings having same contact surface area as that of the solid circular footing. The Present study emphasizes on this fact and a series of experimental tests on the circular and model rings footings were conducted on unreinforced sand, maintaining the inner to outer diameter ratio varying from 0 to 0.8 ( 0 , $0.375,0.555,0.8)$. Various factors and parameters are computed and derived to carefully conclude the effect of same contact surface area on the footing pressure, load and settlement. 


\section{The Experiment}

\subsection{Sand}

In the experiments performed, sun dried medium density river sand was used. The particle size distribution curve was created using the dry sieving method according to the standard of IS-383(1970)[9] method for the given sand. The average particle size distribution curve is shown in Fig. 1. Its coefficient of uniformity $(\mathrm{Cu})$ and coefficient of curvature (Cc), were 2.89 and 1.05, respectively, based on the value of $\mathrm{Cu}$ and $\mathrm{Cc}$ the sand in poorly graded. The properties of sand are given in Table 1.

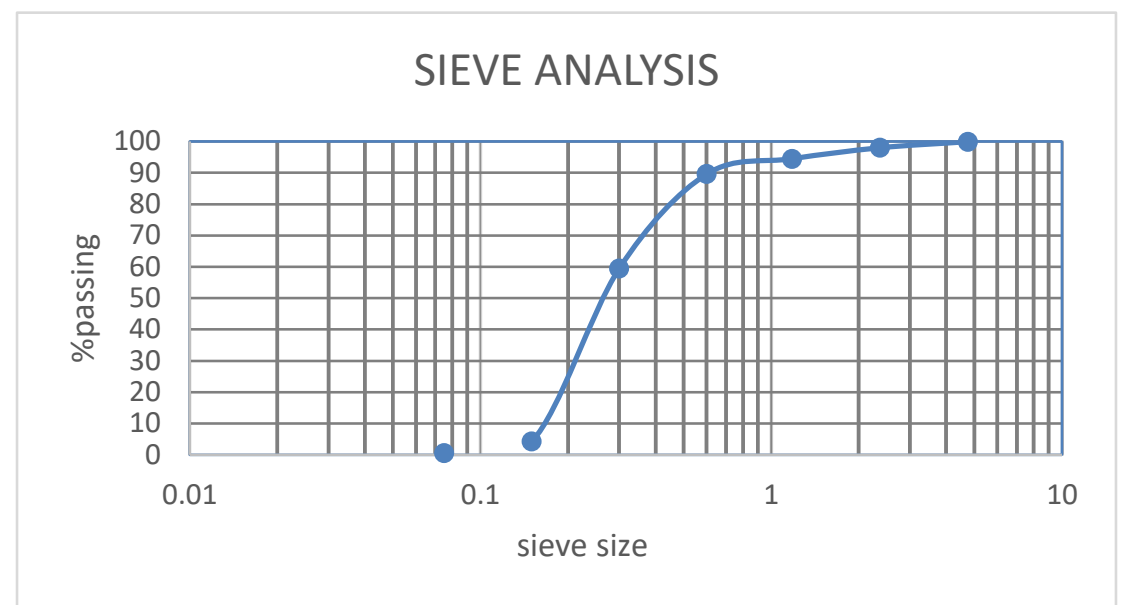

Fig.1: Sieve Analysis according to IS-383 (1970).

Table 1: Properties of the sample.

\begin{tabular}{|c|c|}
\hline Parameter & Value \\
\hline Maximum unit weight (kN/m3) & 16.5 \\
\hline Minimum unit weight (kN/m3) & 14.5 \\
\hline Specific gravity & 2.62 \\
\hline Coefficient of uniformity & 1.764 \\
\hline Coefficient of curvature & 0.949 \\
\hline Relative density during test & $80 \%$ \& $60 \%$ \\
\hline $\begin{array}{c}\text { Angle of Internal Friction } \varphi \\
\text { (60\% Relative Density) }\end{array}$ & $42^{0}$ \\
\hline $\begin{array}{c}\text { Angle of Internal Friction } \varphi \\
\text { (80\% Relative Density) }\end{array}$ & $44^{0}$ \\
\hline
\end{tabular}

\subsection{Footings}

All the footings were made of mild steel. The dimensions of each are depicted below in Table 2 . The actual footings are shown in Fig. 2. 
Table 2: Different Footing Models.

\begin{tabular}{|c|c|c|c|}
\hline Footing Type & External diameter (mm) & Internal Diameter (mm) & Depth(mm) \\
\hline Solid Circular & 150 & 0 & 30 \\
\hline Hollow Circular & 161.5 & 60 & 30 \\
\hline Hollow Circular & 180.1 & 100 & 30 \\
\hline Hollow Circular & 250 & 200 & 30 \\
\hline
\end{tabular}

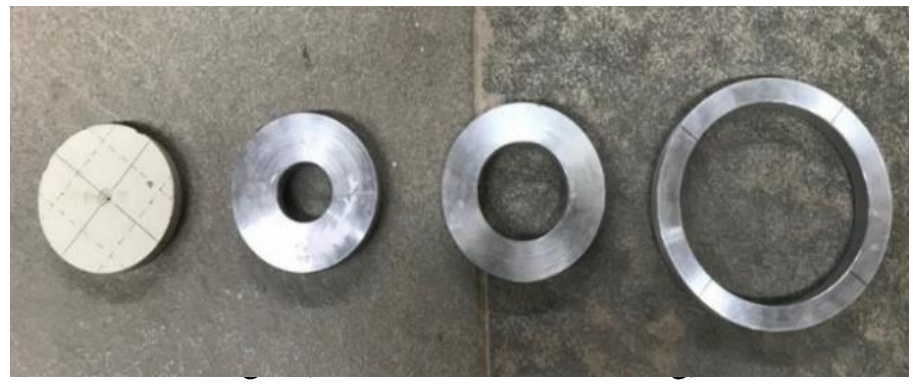

Fig. 2: Different Model Footing.

\subsection{Loading System}

A Reaction truss (Howe type Truss) is used in loading frame having height $=1.65 \mathrm{~m}$ and width $=6 \mathrm{~m}$. It was rested on I-section of height $1.4 \mathrm{~m}$ supported by the concrete foundation of $0.75 \mathrm{~m} * 0.75 \mathrm{~m}$. The Loading system consists of a hydraulic jack arrangement installed below the reaction truss as shown in Fig 3. The footing was vertically loaded with the help of load cell which transfers the load from hydraulic jack to the footing of different diameters via ball bearing arrangement. Load value was noted in a digital indicator which was connected to load cell having a least count of $5 \mathrm{~N}$.

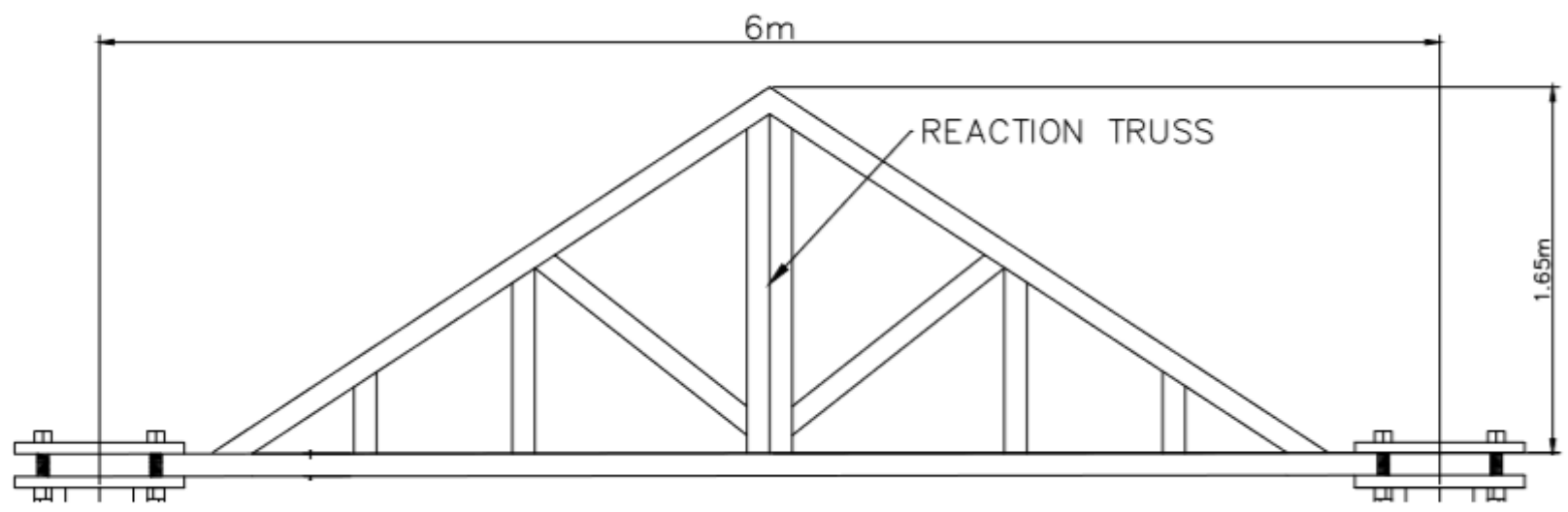

Fig. 3: Howe type Truss.

\subsection{Full Test Apparatus and sample preparation}

A Steel box was fixed in place at the centre of the apparatus. It was filled with the sand. The total depth of the sand sample was kept $500 \mathrm{~mm}$. The sampling of sand was done in layers of $100 \mathrm{~mm}$. Each layer was filled one after the other after the required amount of compaction for the specified relative densities. The required weight of the sand was calculated as per required relative unit weight. Each layer after filling was compacted with the help of vibration motor. After total filling, the 
top layer was levelled carefully. Then the footing was placed below the exact centre of the hydraulic jack with the help of plumb bob. For the vertical displacement measurement of footing, LVDT (Linear Variable Deformation Transducer) was used. It had an accuracy of $0.02 \mathrm{~mm}$ and range of $52 \mathrm{~mm}$. It was placed on the footing and was fixed to steel angles. The steel angles were fixed to the steel tank with G-clamps.

After that, the load cell was placed to transfer the load to footings of different diameters and in the case of hollow circular footing, a strip plate of size less than the hollow circular footing was placed to transfer the load. For load application, a pump and a hydraulic jack were used. A load cell having the capacity of 5000kg was used to transfer the load from jack to the footings. A gradual loading was given till the footing fails or the settlement is more than $10 \%$ of the width of the footing. The Experimental setup of one of the experiments is shown in Fig.4.The data recorded from the LVDT during the test was used to make different graphs.

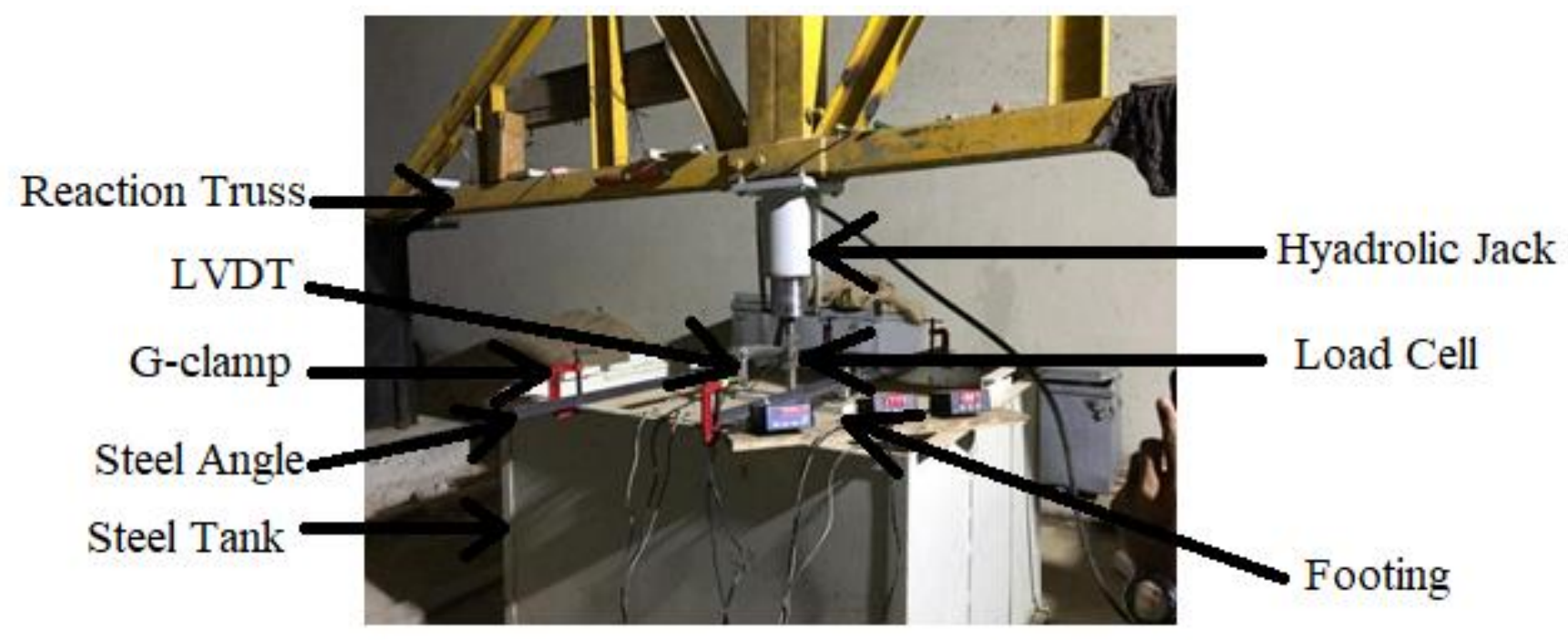

Fig. 4: Experimental Setup.

\section{Results and Graphs}

\subsection{Stress versus Settlement}

The relation between footing pressure and Settlement for both relative densities is plotted and shown in Fig.5-6. The ultimate footing pressure is maximum for solid circular footing and minimum for the ring footing of $\mathrm{n}=0.8$ for both the relative densities. For relative density $=80 \%$, it is observed that the ultimate footing pressure for hollow circular footing having $n=0.375$ is 0.77 times the ultimate footing pressure of the solid circular. Similarly, for $n=0.55$ and $n=0.8$, it is 0.46 times and 0.38 times. It is inferred that the decrease in footing pressure is reasonable for $\mathrm{n}=0.375$, but for $\mathrm{n}=0.55$ and 0.8 the footing pressure reduces very sharply. The curve has a similar nature for the $60 \%$ relative density but with lower footing pressure which is obvious. 


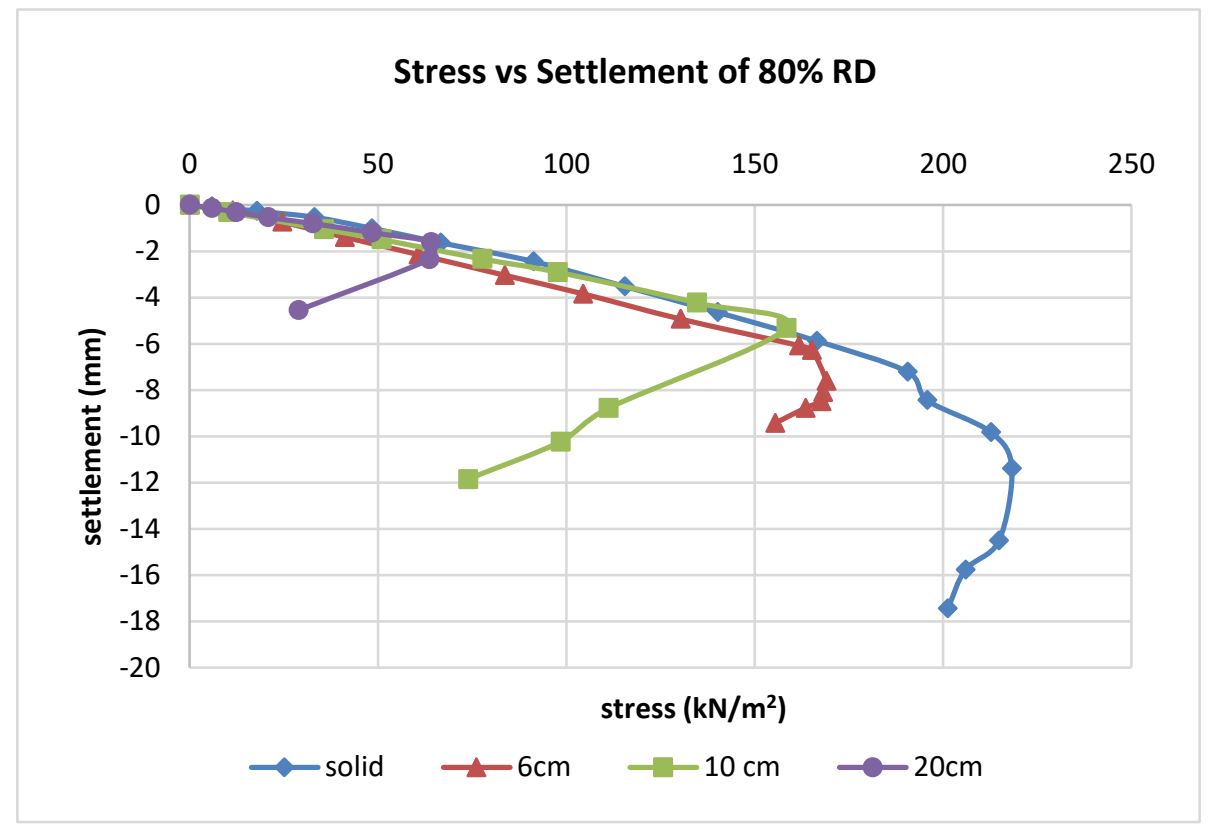

Fig. 5: For 80\% Relative Density.

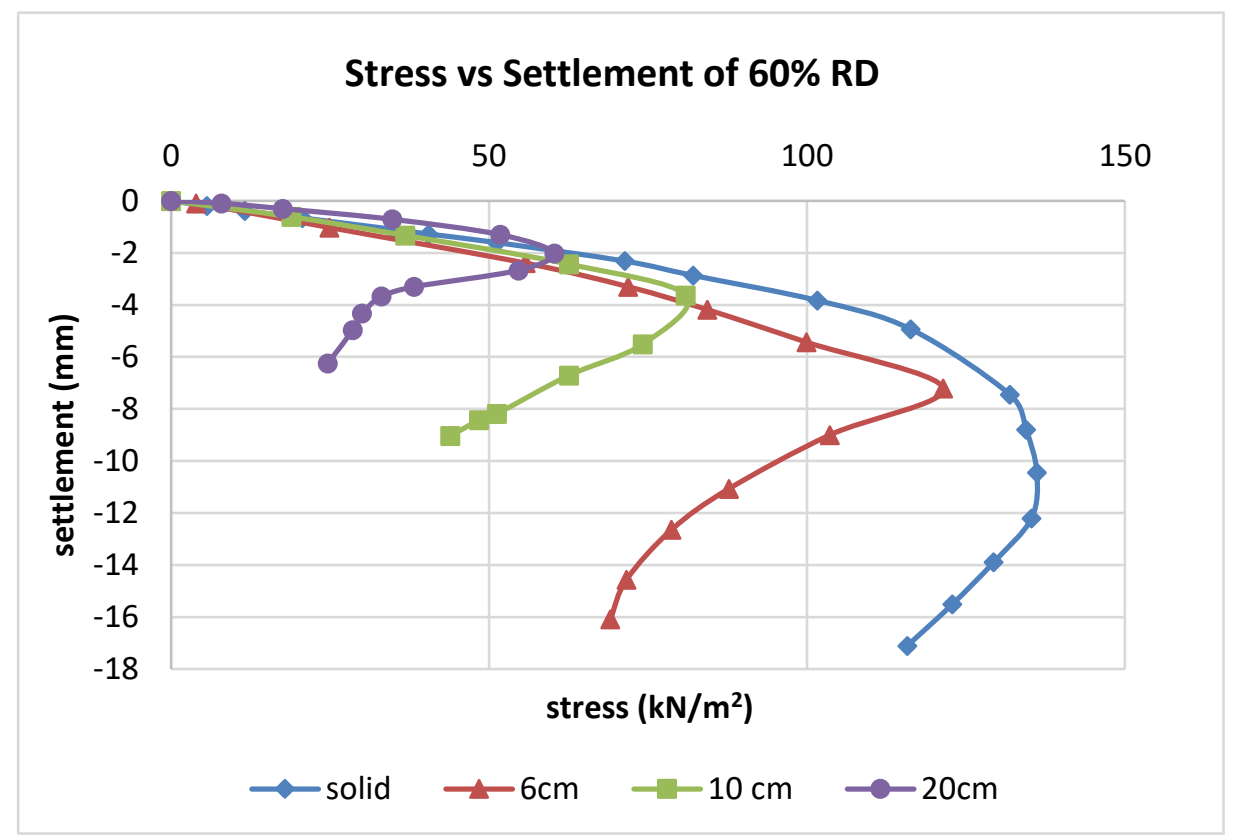

Fig. 6: For 60\% Relative Density.

\subsection{Failure Stress Ratio versus Diameter Ratio}

The graph between the Ring Diameter ratio (Internal diameter to External diameter) and Failure Stress Ratio (Failure stress of different footing to failure stress of solid circular footing) is shown in Fig.9. Footing stress ratio can also be expressed in terms of failure stress of efficiency factor defined as the ratio of failure stress of ring footing with different $\mathrm{n}$ value to the failure stress of solid circular footing. Ring diameter ratio is the ratio of diameter of ring footing to diameter of solid circular 
footing. it is observed that the efficiency from solid Circular to $60 \mathrm{~mm}(\mathrm{n}=.375)$ is about 0.8 times for both $80 \%$ and $60 \%$ Relative Density. Similarly, from $60 \mathrm{~mm}(\mathrm{n}=0.375)$ to $100 \mathrm{~mm}(\mathrm{n}=0.555) 0.6$ times for both $80 \%$ and $60 \%$ Relative Density and from $100 \mathrm{~mm}(\mathrm{n}=0.555)$ to $200 \mathrm{~mm}(\mathrm{n}=0.8)$ is about .6 times for $80 \%$ and $60 \%$ Relative Density.

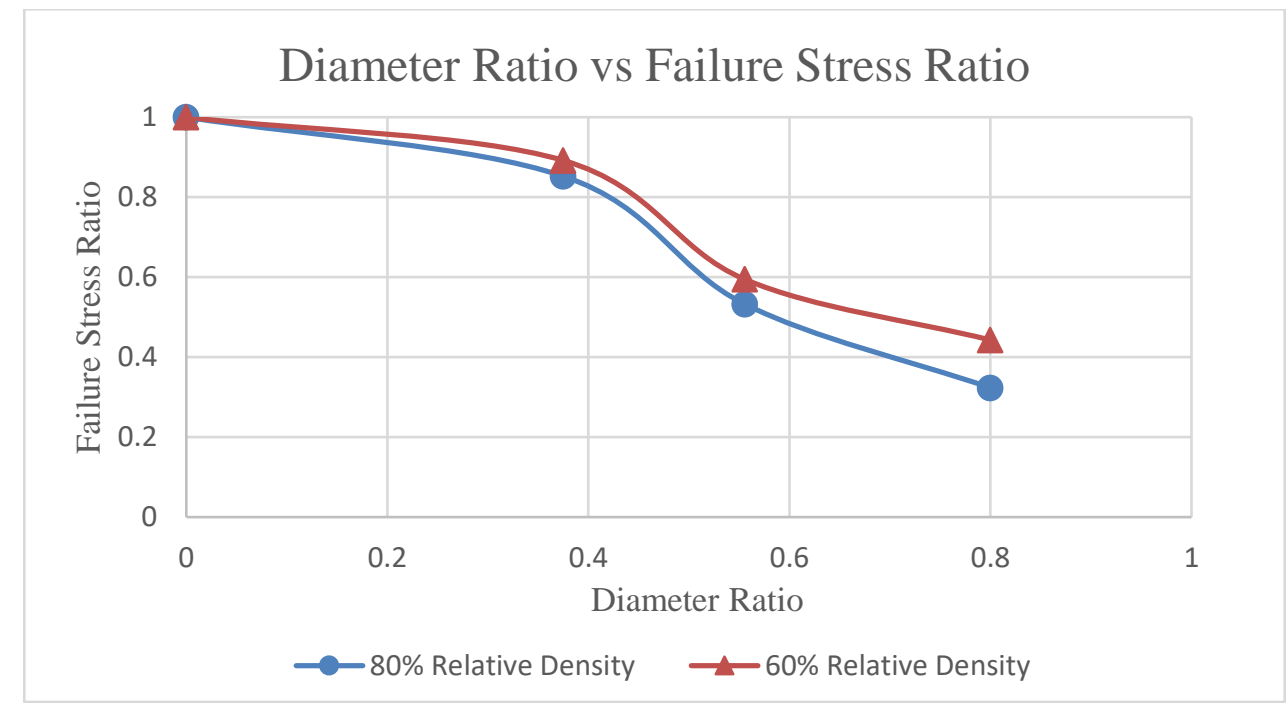

Fig. 7: Relation of Diameter Ratio and Failure Stress Ratio.

\subsection{Comparison between the Bearing Capacity of Experimental Value and Theoretical Value}

The comparison of the Bering Capacity of Experimental Values with the Theoretical Values of Terzaghi's [10] equation is given in Table 3.

$$
\text { Terzaghi Equation for Bearing Capacity }-\mathrm{qu}_{\mathrm{u}}=1.3 \mathrm{cN} \mathrm{N}_{\mathrm{c}}+\gamma \mathrm{DN}_{\mathrm{q}}+.3 \gamma \mathrm{BN}_{\gamma}
$$

Where $\mathrm{q}_{\mathrm{u}}$ - Ultimate bearing capacity $\left(\mathrm{kN} / \mathrm{m}^{2}\right)$

$$
\begin{array}{ll}
\mathrm{c}-\text { cohesion }\left(\mathrm{kN} / \mathrm{m}^{2}\right) & =0 \\
\gamma-\text { Unit weight of soil }\left(\mathrm{kN} / \mathrm{m}^{2}\right) & =15.8 \& 15.15 \\
\mathrm{D}-\text { Depth of footing }(\mathrm{m}) & =0 \\
\mathrm{~B}-\text { Width of footing }(\mathrm{m}) & =0.15 \\
\mathrm{~N}_{\mathrm{c}}, \mathrm{N}_{\mathrm{q}}, \mathrm{N}_{\gamma} \text { Terzaghi's bearing capacity factors }
\end{array}
$$

Table 3: Comparison Between the Bearing Capacity of Experimental Value and Theoretical Value.

\begin{tabular}{|c|c|c|}
\hline Relative Density & $\begin{array}{c}\text { Present Experiment; } \\
\mathrm{q}_{\mathrm{u}}\left(\mathrm{kN} / \mathrm{m}^{2}\right)\end{array}$ & $\begin{array}{c}\text { Terzaghi(1943); } \\
\mathrm{q}_{\mathrm{u}}\left(\mathrm{kN} / \mathrm{m}^{2}\right)\end{array}$ \\
\hline $60 \%$ & 136.16 & 122.19 \\
\hline $80 \%$ & 218.25 & 183.49 \\
\hline
\end{tabular}

\section{Conclusion}

The objective of the experimental research was to study the bearing pressure and settlement variation for the different Ring diameter ratios with same contact surface area. The results obtained are quite tolerable. Performance of the footings in terms of footing pressure is higher for $80 \%$ relative density which is evident. The bearing pressure 
obtained experimentally is compared with the Terzhagi's equation for bearing capacity. Experimental values are slightly higher because of the difficulty in determination of $\varphi$ values. From the Fig. 6-7 it can be observed that the bearing pressure pressure of the footing decreases with the increase in ring diameter ratio, even if the contact surface area of the footing is is kept same as that of solid ring footing, the reason may be due to confining effect. Up to $n=0.375$ the fall is gentle, but afterwards for $n=0.55$ and 0.8 there is a rapid decrease in the footing pressure values. The efficiency of the footings can be be observed in Fig. 9, it is concluded that efficiency of the ring footings with $n=0.8$ is the lowest, after that there is a reasonable increase in the performance of the footing with $n=0.55$. From $n=0.55$ to $n=0.375$ there is a sharp increase in the efficiency of the footing. Difference between the efficiency of the solid ring footing and ring footing with $\mathrm{n}=0.375$ is about $10-15 \%$. The decrease in the efficiency is due to the confining effect i.e. with the increase in " $n$ " value the hole diameter will also increase resulting the decrease in the confining effect. So, we can impart hollowness in circular footing up to a certain ring diameter ratio without much compromise in bearing pressure maintaining same contact surface area. This fact can be used in the design of hollow foundation where there is prerequisite of installation of ring footing.

\section{References}

[1] K. Fisher, "Zur Berechnung der setzung Von Fundamenten in der form einer Kreisformigen Ringflache," Der Bauingenieur, vol. 32, no. 5, pp. 172-4, 1957.

[2] M. L. Ohri, D. G. M. Purhit, M. L. Dubey, "Behavior of ring footings on dune sand overlaying dense sand," in Pres. International Conference of Civil Engineers, Tehran, Iran, 1997.

[3] K. E. Egorov, "Calculation of bed for foundation with ring footing," in Proceedings of the Sixth International Conference on Soil Mechanics and Foundation Engineering, Montreal, Quebec, 1965, pp. 41-45.

[4] N. Hataf, M. R. Razavi, "Behavior of ring footing on sand," Iranian Journal of Science and Technology, Transaction B, vol. 27, pp. 47-56, 2003.

[5] H. Gholami, E. Seyedi Hosseininia, "Bearing capacity factors of ring footings by using the method of Characteristics,” Geotech. Geol.Eng., vol. 35, no. 5, pp. 2137-2146, 2017.

[6] A. Keshavarz, J. Kumar, "Bearing capacity computation for a ring foundation using the stress characteristics Method," Comput.Geotech., 2017.

[7] Masoud Makarchian and Ehsan Badakhshan, "Comparison of Bearing Capacity of Footings with Same Area Resting on Reinforced Sand," International Journal of GEOMATE, vol. 12, No. 29, pp. 9-16, 2017.

[8] Joon Kyu Lee and SangseomJeong, "Immediate Settlement of Ring Footings Resting on Inhomogeneous Finite Stratum," Licensee MDPI, Basel, Switzerland, 2018.

[9] IS-383, "Specification Forcoarse and Fine Aggregates from Natural Sources for Concrete," 1970.

[10] K. Terzaghi, Theoretical Soil Mechanics. New York: John Wiley and Sons, 1943.

[11] IS-1888, "Method of Load Test on Soil," 1982.

[12] M. Naseri, E. Hosseininia, "Experimental Study of Elastic settlement of ring foundations," Soils and Foundations, vol. 55, no. 2, 2015. 